\title{
Expression of CXCL12 and its receptor CXCR4 in esophageal squamous cell carcinoma
}

\author{
KEN SASAKI, SHOJI NATSUGOE, SUMIYA ISHIGAMI, MASATAKA MATSUMOTO, \\ HIROSHI OKUMURA, TETSURO SETOYAMA, YASUTO UCHIKADO, YOSHIAKI KITA, \\ KIYOKAZU TAMOTSU, KOICHI HANAZONO, TETSUHIRO OWAKI and TAKASHI AIKOU \\ Department of Surgical Oncology and Digestive Surgery, Field of Oncology, Course of Advanced Therapeutics,
Kagoshima University Graduate School of Medical and Dental Sciences, Kagoshima 890-8520, Japan
}

Received August 5, 2008; Accepted September 30, 2008

DOI: $10.3892 /$ or_00000190

\begin{abstract}
The chemokine CXCL12, also known as stromal cell-derived factor-1 and its receptor CXCR4 have been shown to play prominent roles in regulating the directional migration and proliferation of various types of cancer cells during the metastatic process. However, few researchers have examined the expression of CXCL12 and CXCR4 and their prognostic value in patients with esophageal squamous cell carcinoma (ESCC). We investigated immunohistochemically the relationship between CXCL12 and CXCR4 expression and clinicopathological factors including prognosis in surgical specimens of primary tumors in 214 patients with ESCC. The positive expression rate of CXCL12 was $53.7 \%$ and that of CXCR4 was $84.6 \%$. Positive CXCL12 expression was significantly correlated with lymph node metastasis, tumor stage, gender and lymphatic invasion. The overall and disease-free survival rate was significantly lower in patients with positive CXCL12 expression than in those with negative CXCL12 expression. The expression of CXCR4 had no correlation with clinicopathological variables and prognosis. We showed that positive CXCL12 expression was related to a greater degree to tumor development, compared with CXCR4 expression. Evaluation of CXCL12 expression is useful for determining tumor properties, including nodal metastasis and prognosis in patients with ESCC.
\end{abstract}

\section{Introduction}

Chemokines are soluble, small molecular weight, secreted proteins and are, to date, the largest known cytokine family.

Correspondence to: Dr Ken Sasaki, Department of Surgical Oncology and Digestive Surgery, Field of Oncology, Course of Advanced Therapeutics, Kagoshima University Graduate School of Medical and Dental Sciences, 8-35-1 Sakuragaoka, Kagoshima 890-8520, Japan

E-mail: k-sasaki@m.kufm.kagoshima-u.ac.jp

Key words: CXCL12, CXCR4, esophageal squamous cell carcinoma, immunohistochemical staining, prognosis
Their receptors regulate a variety of immune responses to infection, inflammation and tissue repair. Besides controling the trafficking of immune cells, chemokines also regulate the migration of several different cell types in embryogenesis. It has been established that cancer cells exploit signaling through seven transmembrane G-protein-coupled chemokine receptors for several steps in the initiation and progression of primary and metastatic cancer (1-5).

In particular, the chemokine CXCL12, also known as stromal cell-derived factor-1 and its receptor CXCR4 have prominent roles in common malignancies including breast, ovarian, prostate, kidney, brain and lung cancers (6-15).

There have been few studies focusing on the protein expression of CXCL12 and CXCR4 in cancer cells (16). The aims of this retrospective study were to examine the relationship between CXCL12 and CXCR4 expression and clinicopathological factors, and to evaluate whether their expression is useful for predicting clinical outcome in surgical specimens from patients with esophageal squamous cell carcinoma (ESCC).

\section{Materials and methods}

Patient characteristics. The present study involved 214 consecutive patients with ESCC (196 men and 18 women) who underwent esophagectomy with lymph node dissection at the Kagoshima University Hospital between January 1987 and December 1998. The patients ranged in age from 36 to 92 years (mean, 64.1 years). Transthoracic esophagectomy by right thoracotomy and left thoracotomy was performed in $174(81.3 \%)$ and 16 patients $(7.5 \%)$, respectively. In addition, transhiatal esophagectomy without thoracotomy and the others were performed in $18(8.4 \%)$ and 6 patients $(2.8 \%)$, respectively. Three-field lymphadenectomy (cervical, mediastinal and abdominal regions) was performed in 93 patients (43.5\%), 2-field lymphadenectomy (mediastinal and abdominal regions) was performed in 119 patients $(55.6 \%)$ and 1 -field (cervical or abdominal region) lymphadenectomy in the remaining 2 patients $(0.9 \%)$. The median number of removed lymph nodes was 47 (range, 1-141). The number of patients with $\mathrm{R} 0$ and $\mathrm{R} 1$ resection was 182 and 32 , respectively. None of these patients underwent endoscopic mucosal resection, preoperative chemotherapy and/or 

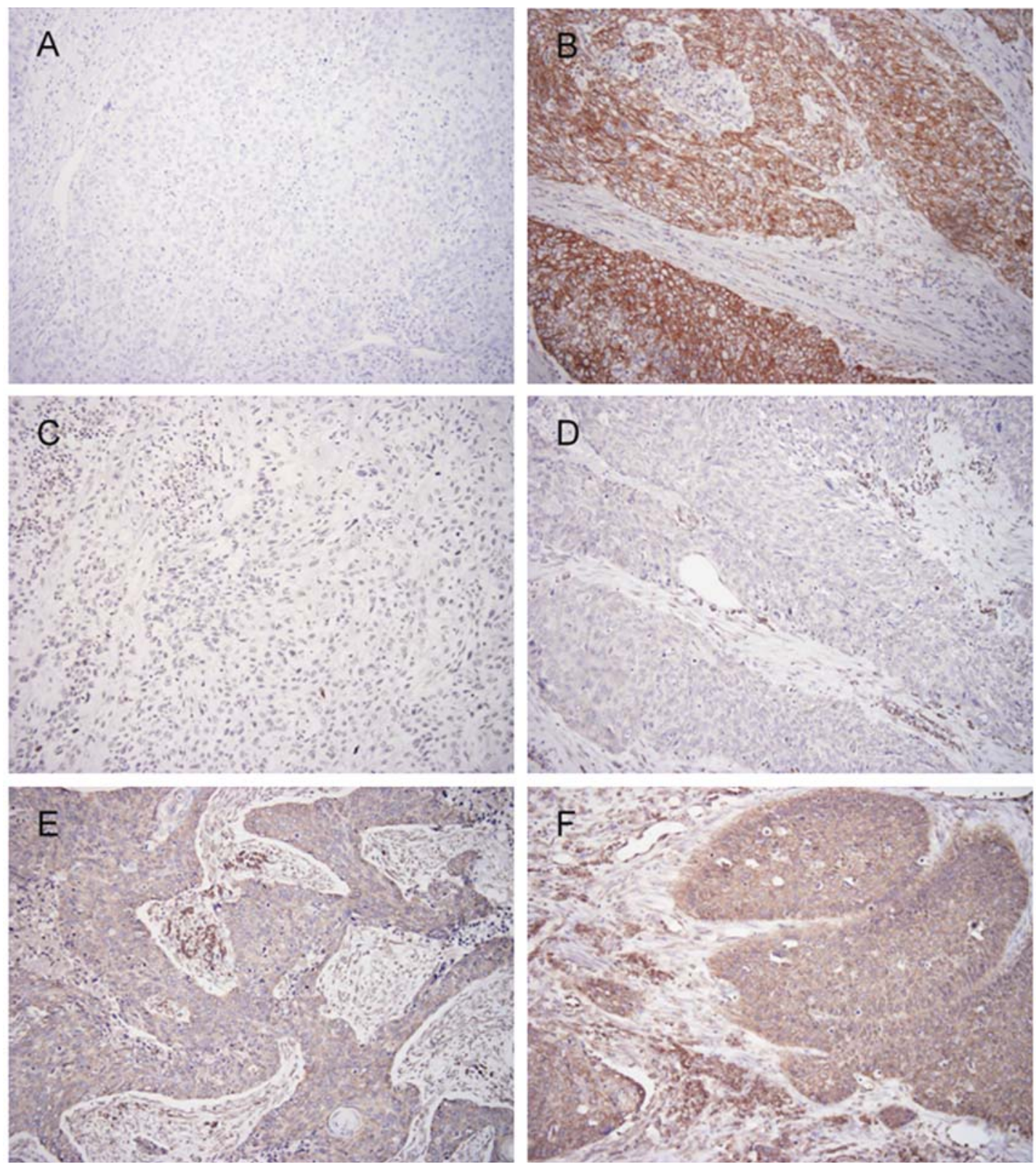

Figure 1. Immunohistochemical detection of CXCL12 and CXCR4 protein expression in ESCCs. (A) Negative expression of CXCL12, (B) positive expression of CXCL12, (C) negative expression of CXCR4, (D) positive expression of CXCR4 with weak intensity, (E) positive expression of CXCR4 with moderate intensity and (F) positive expression of CXCR4 with strong intensity (counterstaining, Mayer's hematoxylin; original magnification, x200).

radiotherapy, and none of them had synchronous or metachronous multiple cancers in other organs. Seventy-three patients had relapsed disease in the follow-up period. Classification of the specimens was determined according to the International Union Against Cancer Tumor-NodeMetastasis Classification System (17). All of the M1 tumors had distant lymph node metastases. All patients were followed up after discharge with a chest X-ray every 1 to 3 months, computed tomography every 3 to 6 months, and ultrasonography every 6 months. Bronchoscopy and endoscopy were performed when necessary. Follow-up data after surgery were available for all patients with a median follow-up period of 42 months (range, 1-181 months). The study was approved by the institutional review board of the hospital, and informed consent was obtained from the patients.
Immunohistochemical analysis. Tumor samples were fixed with $10 \%$ formalin in phosphate-buffered saline (PBS), embedded in paraffin, and sectioned into $4-\mu \mathrm{m}$ slices. They were deparaffinized in xylene and dehydrated with a series of graded ethanol. For antigen retrieval, sections were autoclaved in $10 \mathrm{mM}$ citrate buffer solution for $10 \mathrm{~min}$ at $120^{\circ} \mathrm{C}$. The endogenous peroxidase activity of specimens was blocked by immersing the slides in a $3 \%$ hydrogen peroxide solution in methanol for $30 \mathrm{~min}$ at room temperature. After washing with PBS, the sections were treated with $1 \%$ bovine serum albumin for $30 \mathrm{~min}$ to block nonspecific reactions at room temperature. The blocked sections were incubated with primary antibody CXCL12 (MAB350, 1:200; R\&D Systems, Minneapolis, MN) or CXCR4 (MAB171, 1:200; R\&D Systems) diluted in PBS at room temperature for $45 \mathrm{~min}$, 

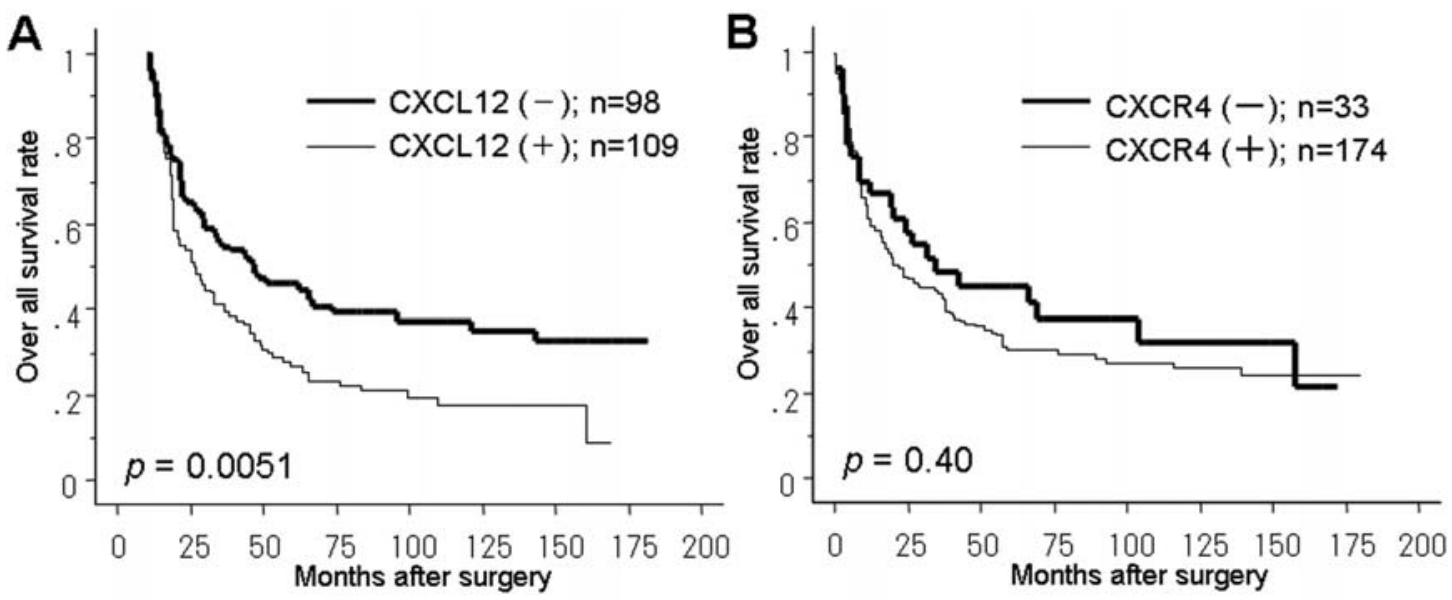

Figure 2. The postoperative overall survival curves according to the expression of CXCL12 (A) and CXCR4 (B) proteins. There was a significant difference in survival between the patients with positive $(+)$ and negative $(-)$ expression of CXCL12 (P=0.0051). There was no significant difference in survival between the patients with positive $(+)$ and negative $(-)$ expression of CXCR4 $(\mathrm{P}=0.40)$.

followed by staining with a streptavidin-biotin peroxidase kit (Nichirei, Tokyo, Japan). The sections were washed in PBS, and the immune complex was visualized by incubating the sections with diaminobenzidine tetrahydrochloride. The sections were rinsed briefly in water, counterstained with hematoxylin and mounted. Normal human tonsil and spleen tissues were used as positive controls for CXCL12 and CXCR4, respectively. Negative controls were created by replacing the primary antibodies with PBS. Evaluation of immunohistochemistry was independently carried out by two investigators (K.S. and S.I.) who were unaware of the clinical data or disease outcome. In cases in which the results of immunohistochemical expression differed between the two observers, slides were evaluated by a third observer (S.N.). Positive expression of CXCL12 was defined as detectable immunoreaction in membrane and cytoplasmic lesions of $>10 \%$ of the cancer cells. CXCR4 expression was divided into two groups according to intensity as follows: CXCR4 negativity was defined as no expression of CXCR4, and CXCR4 positivity was defined as weak to strong intensity of CXCR4 expression. To evaluate expression of CXCL12 and CXCR4, ten fields (within the tumor and at the invasive front) were selected, and expression in 1000 tumor cells (100 cells/ field) was evaluated using high-power (x200) microscopy.

Statistical analysis. Statistical analysis of group differences was carried out using the $\chi^{2}$ and t-tests. The Kaplan-Meier method was used for survival analysis, and differences in survival were estimated using the log-rank test. Prognostic factors were examined by univariate and multivariate analyses (Cox proportional hazards regression model). $\mathrm{P}<0.05$ was considered to be statistically significant. All statistical analyses were perfomed with the software package JMP 5 for Windows (SAS Institute, Inc., Cary, NC).

\section{Results}

Expression of CXCL12 and CXCR4 in esophageal squamous cell carcinoma. The positive expression of CXCL12 and
CXCR4 was detected in both the membrane and the cytoplasm of ESCC. The expression of CXCL12 was observed in $53.7 \%$ of samples, and the expression of CXCR4 was observed in $84.6 \%$ of samples (Fig. 1).

Relationship between the expression of CXCL12 and CXCR4 and clinicopathological findings. The expression of CXCL12 was associated with the following clinicopathological parameters: lymph node metastasis, tumor stage, gender and lymphatic invasion. The tumors with positive CXCL12 expression had more lymph node metastasis and greater lymphatic invasion than those with negative CXCL12 expression ( $\mathrm{P}=0.0004$ and $\mathrm{P}=0.0166$, respectively). The expression of CXCR4 had no correlation with the clinicopathological variables. The expression of CXCL12 and CXCR4 had a weak correlation $(\mathrm{P}=0.072)$ (Table I).

Relationship between clinical outcome and expression of CXCL12 and CXCR4. Seven of the patients died of postoperative complications within 30 days of the beginning of the study period, leaving 207 patients for survival analysis, and 32 patients underwent palliative resection. The number of palliative resection patients with stage IIA, III, IVA and IVB were $1,11,3$ and 17, respectively. There was a significant difference in overall survival rates between negative and positive expression of CXCL12 ( $\mathrm{P}=0.0051$; Fig. $2 \mathrm{~A}$ ). On the other hand, no significant difference was found between overall survival rates and CXCR4 expression (Fig. 2B). There was a significant difference in disease-free survival rates between negative and positive expression of CXCL12 $(\mathrm{P}=0.0036$; Fig. 3A). On the other hand, no significant difference was found between disease-free survival rates and CXCR4 expression (Fig. 3B).

Univariate and multivariate analyses of survival. Univariate analysis showed that the following factors were significantly related to postoperative survival: gender, tumor depth, lymph node metastasis, distant metastasis, stage, lymphatic invasion, venous invasion and CXCL12 expression. Multivariate 
Table I. CXCL12 and CXCR4 expression in relation to clinicopathological findings.

\begin{tabular}{|c|c|c|c|c|c|c|c|}
\hline \multirow[b]{2}{*}{ Characteristics } & \multirow[b]{2}{*}{$\begin{array}{c}\text { Total } \\
\mathrm{n}=214\end{array}$} & \multicolumn{2}{|c|}{ CXCL12 expression } & \multirow[b]{2}{*}{$\mathrm{P}$} & \multicolumn{2}{|c|}{ CXCR4 expression } & \multirow[b]{2}{*}{$\mathrm{P}$} \\
\hline & & $\begin{array}{c}\text { Positive } \\
\mathrm{n}=115(53.7 \%)\end{array}$ & $\begin{array}{c}\text { Negative } \\
\mathrm{n}=99(46.3 \%)\end{array}$ & & $\begin{array}{c}\text { Positive } \\
\mathrm{n}=181(84.6 \%)\end{array}$ & $\begin{array}{c}\text { Negative } \\
\mathrm{n}=33(15.4 \%)\end{array}$ & \\
\hline Mean age $\pm \mathrm{SD}$ & & $65.1 \pm 9.7$ & $62.9 \pm 8.2$ & 0.21 & $64.0 \pm 9.4$ & $64.3 \pm 6.4$ & 0.58 \\
\hline \multicolumn{8}{|l|}{ Gender } \\
\hline Male & $196(91.6)$ & $110(95.7)$ & 86 (86.9) & \multirow[t]{2}{*}{0.020} & 165 (91.2) & $31(93.9)$ & \multirow[t]{2}{*}{0.55} \\
\hline Female & $18 \quad(8.4)$ & $5 \quad(4.4)$ & $13(13.1)$ & & $16 \quad(8.8)$ & $2(6.1)$ & \\
\hline \multicolumn{8}{|l|}{ Tumor location } \\
\hline Upper & $34(15.9)$ & $23(20.0)$ & $11(11.1)$ & \multirow[t]{3}{*}{0.20} & $31 \quad(17.1)$ & $3 \quad(9.1)$ & \multirow[t]{3}{*}{0.42} \\
\hline Middle & $10750.0)$ & $54(47.0)$ & $53(53.5)$ & & 88 (48.6) & $19(57.6)$ & \\
\hline Lower & $73(34.1)$ & $38(33.0)$ & 35 (35.4) & & $62(34.3)$ & $11(33.3)$ & \\
\hline \multicolumn{8}{|l|}{ Histology } \\
\hline Well & $80(37.4)$ & $35(30.4)$ & $45 \quad(45.5)$ & \multirow[t]{3}{*}{0.075} & 71 (39.2) & $9(27.3)$ & \multirow[t]{3}{*}{0.40} \\
\hline Moderate & $98(45.8)$ & $58(50.4)$ & $40 \quad(40.4)$ & & 81 (44.8) & $17(51.5)$ & \\
\hline Poor & $36(16.8)$ & $22(19.1)$ & $14(14.1)$ & & $29(16.0)$ & $7(21.2)$ & \\
\hline \multicolumn{8}{|l|}{$\mathrm{pT}$} \\
\hline pT1 & $56(26.2)$ & $25(21.7)$ & 31 (31.3) & \multirow[t]{4}{*}{0.14} & 45 (24.9) & $11(33.3)$ & \multirow[t]{4}{*}{0.28} \\
\hline pT2 & $31(14.5)$ & $19(16.5)$ & $12(12.1)$ & & $24(13.3)$ & $7(21.2)$ & \\
\hline pT3 & $88(41.1)$ & $45(39.1)$ & 43 (43.4) & & 79 (43.7) & $9(27.3)$ & \\
\hline pT4 & 39 (18.2) & $26(22.6)$ & $13(13.1)$ & & 33 (18.2) & $6(18.2)$ & \\
\hline \multicolumn{8}{|l|}{$\mathrm{pN}$} \\
\hline pNO & $81(37.9)$ & $31 \quad(27.0)$ & $50 \quad(50.5)$ & \multirow[t]{2}{*}{0.0004} & 65 (35.9) & $16(48.5)$ & \multirow[t]{2}{*}{0.18} \\
\hline $\mathrm{pN} 1$ & $133(62.2)$ & $84(73.0)$ & 49 (49.5) & & $116(64.1)$ & $17(51.5)$ & \\
\hline \multicolumn{8}{|l|}{$\mathrm{pM}$} \\
\hline $\mathrm{pM} 0$ & $152(71.0)$ & $76(66.1)$ & 76 (76.8) & \multirow[t]{2}{*}{0.084} & 126 (69.6) & $26(78.8)$ & \multirow[t]{2}{*}{0.27} \\
\hline pM1 & $62(29.0)$ & 39 (33.9) & $23 \quad(23.2)$ & & 55 (30.4) & 7 (21.2) & \\
\hline \multicolumn{8}{|l|}{ pStage } \\
\hline I & 37 (17.3) & $14(12.2)$ & $23 \quad(23.2)$ & 0.0076 & $29(16.0)$ & $8(24.2)$ & 0.32 \\
\hline IIA & 37 (17.3) & 13 (11.3) & $24 \quad(24.2)$ & & 30 (16.6) & $7(21.2)$ & \\
\hline IIB & 25 (11.7) & $15(13.0)$ & $10(10.1)$ & & $19(10.5)$ & $6(18.2)$ & \\
\hline III & $53(24.8)$ & 34 (29.6) & 19 (19.2) & & $48 \quad(26.5)$ & $5(15.2)$ & \\
\hline IVA & $17 \quad(7.9)$ & 13 (11.3) & $4 \quad(4.0)$ & & $16 \quad(8.8)$ & $1 \quad(3.0)$ & \\
\hline IVB & $45(21.0)$ & $26(22.6)$ & 19 (19.2) & & 39 (21.6) & $6(18.2)$ & \\
\hline Lymphatic invas & & & & & & & \\
\hline Positive & $137(64.0)$ & 82 (71.3) & 55 (55.6) & 0.017 & $120(66.3)$ & $17(51.5)$ & 0.11 \\
\hline Negative & $77(36.0)$ & 33 (28.7) & 44 (44.4) & & 61 (33.7) & $16(48.5)$ & \\
\hline Venous invasion & & & & & & & \\
\hline Positive & 74 (34.6) & $42(36.5)$ & 32 (32.3) & 0.52 & 65 (35.9) & $9(27.3)$ & 0.33 \\
\hline Negative & $140(65.4)$ & $73(63.5)$ & 67 (67.7) & & $116(64.1)$ & $24(72.7)$ & \\
\hline CXCR4 express & & & & & & & \\
\hline Positive & $181(84.6)$ & $102(88.7)$ & 79 (79.8) & 0.072 & & & \\
\hline Negative & $33(15.4)$ & 13 (11.3) & $20 \quad(20.2)$ & & & & \\
\hline
\end{tabular}

regression analysis indicated that depth of invasion and distant lymph node metastasis were independent prognostic factors but not CXCL12 expression (Table II).

\section{Discussion}

Many studies of the CXCR4/CXCL12 pathway have been reported, mainly in the field of immunology and infection, in areas such as hematopoiesis, lymphocyte homing and HIV infection. In 2001, Muller et al showed that CXCR4 was expressed more highly in breast cancer tissue than in normal breast tissue and that CXCL12 was expressed in many organs, such as lymph nodes, bone marrow and lungs, in which breast cancer metastasis was often found, but not expressed in kidneys, where metastasis hardly occurred. In addition, studies in vivo showed that injecting an antibody which neutralizes 

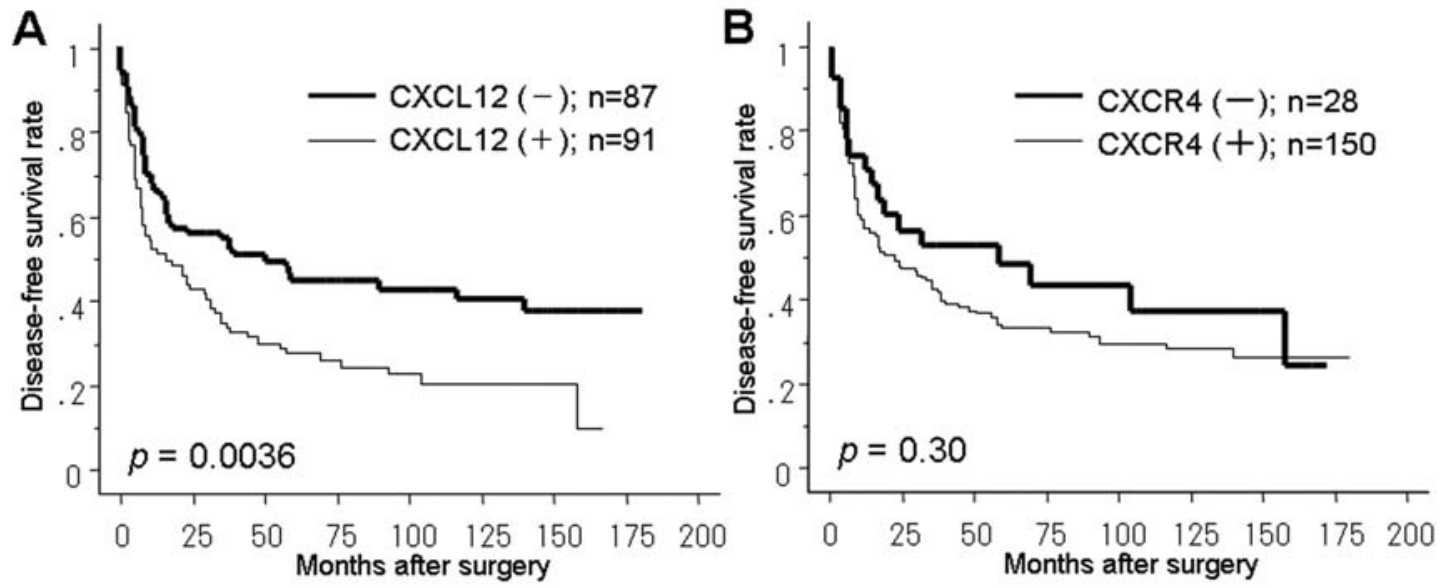

Figure 3. The postoperative disease-free survival curves according to the expression of CXCL12 (A) and CXCR4 (B) proteins. There was a significant difference in disease-free survival between the patients with positive $(+)$ and negative (-) expressions of $\mathrm{CXCL12}(\mathrm{P}=0.0036)$. There was no significant difference in disease-free survival between the patients with positive (+) and negative (-) expression of $\mathrm{CXCR} 4(\mathrm{P}=0.30)$.

Table II. Univariate and multivariate analyses of prognostic factors in ESCC.

\begin{tabular}{|c|c|c|c|c|}
\hline Independent factors & Univariate $\mathrm{P}$ & Multivariate $\mathrm{P}$ & Hazard ratio & $95 \%$ confidence interval \\
\hline \multicolumn{5}{|l|}{$\mathrm{pT}$} \\
\hline$(\mathrm{pT} 1,2 / \mathrm{pT} 3,4)$ & $<0.0001$ & $<0.0001$ & 2.317 & $1.590-3.431$ \\
\hline \multicolumn{5}{|l|}{$\mathrm{pN}$} \\
\hline$(\mathrm{pN} 0 / \mathrm{pN} 1$ & $<0.0001$ & 0.2530 & 1.349 & $0.808-2.271$ \\
\hline \multicolumn{5}{|l|}{$\mathrm{pM}$} \\
\hline (pM0/pM1) & $<0.0001$ & 0.0009 & 1.946 & $1.312-2.898$ \\
\hline $\begin{array}{l}\text { Lymphatic invasion } \\
\text { (negative/positive) }\end{array}$ & $<0.0001$ & 0.4980 & 1.186 & $0.727-1.954$ \\
\hline $\begin{array}{l}\text { Venous invasion } \\
\text { (negative/positive) }\end{array}$ & 0.0020 & 0.7570 & 1.061 & $0.730-1.537$ \\
\hline $\begin{array}{l}\text { CXCL12 } \\
\text { (negative/positive) }\end{array}$ & 0.0056 & 0.2620 & 1.216 & $0.865-1.722$ \\
\hline $\begin{array}{l}\text { Gender } \\
\text { (female/male) }\end{array}$ & 0.0229 & 0.1200 & 1.670 & $0.884-3.582$ \\
\hline
\end{tabular}

CXCR4 activity led to the inhibition of metastasis to bone marrow and lungs (15). Subsequently, researchers began to become interested in the role of the CXCR4/CXCL12 pathway in tumors. We report for the first time, to the best of our knowledge, that CXCL12 was expressed in ESCC and that its expression was associated with overall survival and the clinicopathological parameters; nodal metastasis, lymphatic invasion, tumor stage and gender. There have been no reports disclosing the clinical implications of chemokine positivity in tumor cells, except for some reports on CXCL12 expression in glioma cells (18), epithelial ovarian cancer cells (16) and oral squamous cell carcinoma (19). CXCL12 expression significantly correlated well with prognosis in glioma, but not in epithelial ovarian cancer cells and oral squamous cell carcinoma. Although the positive expression of CXCL12 was not an independent prognostic factor upon multivariate analysis in this study, its expression correlated well with nodal metastasis and lymphatic invasion. Thus, these results suggest that positive CXCL12 expression has the potential to become an important predictor of lymphogenous metastasis and poor prognosis.

Although the relationship between CXCR4 expression and malignant potentiality has been investigated in various types of cancer, the clinical significance is still controversial (19-22). The role of CXCR4 in cancer metastasis is still debated, because CXCR4 mRNA expression was not found to be significantly different between cancer and noncancerous tissues in the colon, esophagus and stomach (23). According to studies in which CXCR4 expression was immunohistochemically examined in esophageal and gastric cancers, no correlation was found between CXCR4 expression and prognosis $(24,25)$. These results were in agreement with ours. 
In several types of cancer cells, the function of CXCR4 in cell migration in response to CXCL12 has been reported (6-15). Although the mechanism by which the CXCL12/ CXCR4 pathway enhances cell migration has not been fully evaluated, several investigators have shown that CXCL12/ CXCR4 interaction induces matrix metalloproteinases in megakaryocytes (26), rhabdomyosarcoma cells (27) and $\mathrm{CD}^{2} 4^{+}$cells (28). CXCL12/CXCR4 interaction stimulates the phosphatidylinositol-3-kinase pathway that subsequently activates the protein kinase Akt (PI3K/Akt pathway) $(8,29,30)$, mitogen-activated protein kinase pathway (MAPK pathway) (31), extracellular signal-related kinase-1/2 (ERK $1 / 2$ pathway) $(6,13,29)$, and Janus kinase/signal transducer and activator of transcription pathways (JAK/ STAT pathway) (2) in carcinoma cells. Furthermore, CXCL12/ CXCR4 interaction induces the tyrosine phosphorylation of focal adhesion kinase and of RAFTK/Pyk2 (32). CXCL12/ CXCR4 also promotes adhesion to components of the extracellular matrix, including collagen and fibronectin, through integrins $\alpha 2, \alpha 4, \alpha 5$ and $\alpha 1$ (33). On the other hand, the SlitRobo pathway was reported to be a negative regulator of CXCL12/CXCR4 functions (2), and Katayama et al showed that INF- $\gamma$ down-regulated both gene and cell surface protein expression of CXCR4 in certain head and neck squamous cell carcinoma cells (34).

CXCL12/CXCR4 has been widely implicated in the promotion of angiogenesis. CXCR4 has been found to be expressed on human intestinal microvascular endothelial cells, and CXCL12 can stimulate chemotaxis and proliferation of these cells in addition to promoting endothelial tube formation (35). CXCL12 was also found to increase the expression of VEGF by endothelial cells, and in a positive feedback loop, VEGF was found to up-regulate CXCR4 on endothelial cells (36). Additionally, the inhibition of the CXCL12/CXCR4 pathway was found to decrease the growth of gastrointestinal tumors through the suppression of angiogenesis (37). On the other hand, CXCL12/CXCR4 was found to mediate metastasis, but not angiogenesis, in kidney, breast and non-small cell lung cancer $(6,7,15)$. We also examined the relationship between CXCL12/CXCR4 expression and microvessel density in 86 submucosal ESCCs; close relationships were not found (38). Further studies are needed to clarify the role of the CXCL12/CXCR4 pathway in cancer cells since a number of factors were correlated with this pathway.

In the present study, we found that the examination of CXCL12 expression is useful to predict lymph node metastasis and clinical outcome. Alternatively, this pathway could be targeted by blocking the expression of CXCR 4 in tumor cells or the secretion of CXCL12 by tumor cells and stromal cells in the tumor microenvironment. Various blocking agents against CXCR4 have been developed $(39,40)$, and these agents should be used to validate this chemokine receptor as a molecular target for the treatment of patients with ESCC who have not received toxic systemic treatment.

In conclusion, cancerous CXCL12 expression played a more significant role in properties associated with malignancy compared with CXCR4 expression in this study. Evaluation of CXCL12 expression is useful for determining tumor properties, including nodal metastasis and prognosis in patients with ESCC.

\section{Acknowledgements}

We thank our laboratory assistants for their technical support. This study was supported in part by grants-in-aid for scientific research from the Ministry of Education, Science, Sports and Culture, Japan (grant nos. 17390373 and 19591549).

\section{References}

1. Zlotnik A and Yoshie O: Chemokines: a new classification system and their role in immunity. Immunity 12: 121-127, 2000.

2. Luker KE and Luker GD: Functions of CXCL12 and CXCR4 in breast cancer. Cancer Lett 238: 30-41, 2006.

3. Lapidot T, Dar A and Kollet O: How do stem cells find their way home? Blood 106: 1901-1910, 2005.

4. Kulbe H, Levinson NR, Balkwill F and Wilson JL: The chemokine network in cancer - much more than directing cell movement. Int J Dev Biol 48: 489-496, 2004.

5. Burger JA and Kipps TJ: CXCR4: a key receptor in the crosstalk between tumor cells and their microenvironment. Blood 107: 1761-1767, 2006.

6. Phillips RJ, Burdick MD, Lutz M, Belperio JA, Keane MP and Strieter RM: The stromal derived factor-1/CXCL12-CXC chemokine receptor 4 biological axis in non-small cell lung cancer metastases. Am J Respir Crit Care Med 167: 1676-1686, 2003.

7. Schrader AJ, Lechner O, Templin M, et al: CXCR4/CXCL12 expression and signalling in kidney cancer. Br J Cancer 86: 1250-1256, 2002.

8. Kijima T, Maulik G, Ma PC, et al: Regulation of cellular proliferation, cytoskeletal function, and signal transduction through CXCR4 and c-Kit in small cell lung cancer cells. Cancer Res 62: 6304-6311, 2002.

9. Taichman RS, Cooper C, Keller ET, Pienta KJ, Taichman NS and McCauley LK: Use of the stromal cell-derived factor-1/ CXCR4 pathway in prostate cancer metastasis to bone. Cancer Res 62: 1832-1837, 2002.

10. Scotton CJ, Wilson JL, Milliken D, Stamp G and Balkwill FR: Epithelial cancer cell migration: a role for chemokine receptors? Cancer Res 61: 4961-4965, 2001.

11. Uchida D, Begum NM, Almofti A, et al: Possible role of stromalcell-derived factor-1/CXCR4 signaling on lymph node metastasis of oral squamous cell carcinoma. Exp Cell Res 290: 289-302, 2003.

12. Zhou Y, Larsen PH, Hao C and Yong VW: CXCR4 is a major chemokine receptor on glioma cells and mediates their survival. J Biol Chem 277: 49481-49487, 2002.

13. Hwang JH, Hwang JH, Chung HK, et al: CXC chemokine receptor 4 expression and function in human anaplastic thyroid cancer cells. J Clin Endocrinol Metab 88: 408-416, 2003.

14. Mori T, Doi R, Koizumi M, et al: CXCR4 antagonist inhibits stromal cell-derived factor 1-induced migration and invasion of human pancreatic cancer. Mol Cancer Ther 3: 29-37, 2004.

15. Muller A, Homey B, Soto H, et al: Involvement of chemokine receptors in breast cancer metastasis. Nature 410: 50-56, 2001.

16. Jiang YP, Wu XH, Shi B, Wu WX and Yin GR: Expression of chemokine CXCL12 and its receptor CXCR4 in human epithelial ovarian cancer: an independent prognostic factor for tumor progression. Gynecol Oncol 103: 226-233, 2006.

17. Sobin LH and Fleming ID: TNM Classification of Malignant Tumors. 5th edition (1997). Union Internationale Contre le Cancer and the American Joint Committee on Cancer. Cancer 80: 1803-1804, 1997.

18. Salmaggi A, Gelati M, Pollo B, et al: CXCL12 expression is predictive of a shorter time to tumor progression in low-grade glioma: a single-institution study in 50 patients. J Neurooncol 74: 287-293, 2005.

19. Almofti A, Uchida D, Begum NM, et al: The clinicopathological significance of the expression of CXCR4 protein in oral squamous cell carcinoma. Int J Oncol 25: 65-71, 2004.

20. Schimanski CC, Schwald S, Simiantonaki N, et al: Effect of chemokine receptors CXCR4 and CCR7 on the metastatic behavior of human colorectal cancer. Clin Cancer Res 11: 1743-1750, 2005. 
21. Laverdiere C, Hoang BH, Yang R, et al: Messenger RNA expression levels of CXCR4 correlate with metastatic behavior and outcome in patients with osteosarcoma. Clin Cancer Res 11: 2561-2567, 2005.

22. Kaifi JT, Yekebas EF, Schurr P, et al: Tumor-cell homing to lymph nodes and bone marrow and CXCR4 expression in esophageal cancer. J Natl Cancer Inst 97: 1840-1847, 2005.

23. Mitra P, Shibuta K, Mathai J, et al: CXCR4 mRNA expression in colon, esophageal and gastric cancers and hepatitis $\mathrm{C}$ infected liver. Int J Oncol 14: 917-925, 1999.

24. Gockel I, Schimanski CC, Heinrich C, et al: Expression of chemokine receptor CXCR4 in esophageal squamous cell and adenocarcinoma. BMC Cancer 6: 290, 2006

25. Kwak MK, Hur K, Park DJ, et al: Expression of chemokine receptors in human gastric cancer. Tumour Biol 26: 65-70, 2005.

26. Lane WJ, Dias S, Hattori K, et al: Stromal-derived factor 1induced megakaryocyte migration and platelet production is dependent on matrix metalloproteinases. Blood 96: 4152-4159, 2000.

27. Libura J, Drukala J, Majka M, et al: CXCR4-SDF-1 signaling is active in rhabdomyosarcoma cells and regulates locomotion, chemotaxis, and adhesion. Blood 100; 2597-2606, 2002.

28. Janowska-Wieczorek A, Marquez LA, Dobrowsky A, Ratajczak MZ and Cabuhat ML: Differential MMP and TIMP production by human marrow and peripheral blood CD34(+) cells in response to chemokines. Exp Hematol 28: 1274-1285, 2000.

29. Barbero S, Bonavia R, Bajetto A, et al: Stromal cell-derived factor 1alpha stimulates human glioblastoma cell growth through the activation of both extracellular signal-regulated kinases 1/2 and Akt. Cancer Res 63; 1969-1974, 2003.

30. Fresno Vara JA, Casado E, de Castro J, Cejas P, Belda-Iniesta C and Gonzalez-Baron M: PI3K/Akt signalling pathway and cancer. Cancer Treat Rev 30: 193-204, 2004.

31. Chang L and Karin M: Mammalian MAP kinase signalling cascades. Nature 410: 37-40, 2001
32. Fernandis AZ, Prasad A, Band H, Klosel R and Ganju RK: Regulation of CXCR4-mediated chemotaxis and chemoinvasion of breast cancer cells. Oncogene 23: 157-167, 2004.

33. Hartmann TN, Burger JA, Glodek A, Fujii N and Burger M: CXCR4 chemokine receptor and integrin signaling co-operate in mediating adhesion and chemoresistance in small cell lung cancer (SCLC) cells. Oncogene 24: 4462-4471, 2005.

34. Katayama A, Ogino T, Bandoh N, Nonaka S and Harabuchi Y: Expression of CXCR4 and its down-regulation by IFN-gamma in head and neck squamous cell carcinoma. Clin Cancer Res 11: 2937-2946, 2005.

35. Heidemann J, Ogawa H, Rafiee P, et al: Mucosal angiogenesis regulation by CXCR 4 and its ligand CXCL12 expressed by human intestinal microvascular endothelial cells. Am J Physiol Gastrointest Liver Physiol 286: G1059-G1068, 2004.

36. Salcedo R, Wasserman K, Young HA, et al: Vascular endothelial growth factor and basic fibroblast growth factor induce expression of CXCR4 on human endothelial cells: In vivo neovascularization induced by stromal-derived factor-1alpha. Am J Pathol 154: 1125-1135, 1999.

37. Guleng B, Tateishi K, Ohta M, et al: Blockade of the stromal cell-derived factor-1/CXCR4 axis attenuates in vivo tumor growth by inhibiting angiogenesis in a vascular endothelial growth factor-independent manner. Cancer Res 65: 5864-5871, 2005.

38. Sasaki K, Natsugoe S, Ishigami S, et al: Expression of CXCL12 and its receptor CXCR4 correlates with lymph node metastasis in submucosal esophageal cancer. J Surg Oncol 97: 433-438, 2008.

39. Tamamura H, Hori A, Kanzaki N, et al: T140 analogs as CXCR4 antagonists identified as anti-metastatic agents in the treatment of breast cancer. FEBS Lett 550: 79-83, 2003.

40. Liang Z, Wu T, Lou H, et al: Inhibition of breast cancer metastasis by selective synthetic polypeptide against CXCR4. Cancer Res 64: 4302-4308, 2004. 